\title{
A relação capital-trabalho na economia do conhecimento
}

\section{BOUZID IZERROUGENE*}

Capital-labor relations in the knowledge economy. The knowledge economy arises by the promotion of abstract and cooperative labor. This social labor is a product of intellectual and linguistic energy, which leads to mutations about capital accumulation and capital labor relations.

Keywords: knowledge; living labor; communications net; innovation; exploration.

JEL Classification: J24.

\section{INTRODUÇÃO}

Na perspectiva da economia do conhecimento, o trabalho se insere num mundo comunitário, formado e partilhado intersubjetivamente em redes humanas de cooperação, onde a informação assume uma dimensão expressiva e constitutiva da vida social (Quéré, 1991). Entender essa dimensão simbólica como elemento construtivo da realidade social significa atribuir ao conhecimento uma dimensão instauradora que, inscrita nos processos de criação de valor, ganha uma dimensão própria que participa da reconfiguração dos processos de acumulação capitalista, das formas institucionais de regulação e das relações entre a produção e as forças produtivas.

A economia do conhecimento designa uma transformação estrutural que se estende à totalidade do espaço social, através da importância das externalidades associadas ao saber e seus efeitos sobre a organização e a divisão técnica do traba-

\footnotetext{
* Curso mestrado na Universidade Federal da Bahia. E-mail: bouzid@ufba.br. Submetido: Janeiro 2008; Aprovado: Maio 2009.
} 
lho. A captação de ganhos correntes e antecipados que derivam do conhecimento e da inovação se torna meio central para a acumulação do capital. Mesmo os setores de baixa intensidade tecnológica se alinham sobre o modelo de crescimento via inovação.

Para entender a natureza da economia do conhecimento, deve-se, como ponto de partida, admitir que a criação do valor econômico tende a se concentrar na produção de conhecimento por meio do conhecimento, conferindo maior importância ao trabalho intelectual: um trabalho criativo que se forma em redes humanas de cooperação e valorização; um trabalho vivo e complexo que corresponde a um quase capital, ao capital fixo being man himself de Marx, que o capital não consegue dominar apenas através do controle dos meios materiais de produção. Em seguida, é necessário perceber a especificidade da mutação informacional em que a inovação não é apenas uma questão de investimento em bens de capital e criação de novos produtos. Essa especificidade está na prioridade dada ao lugar da inteligência humana no processo de produção e reorganização das relações sociais em redes de comunicação.

No contexto de produção lingüística e cooperativa, a circulação e a produção formam um só conjunto, de um modo que remove as fronteiras entre o uso e a criação. Os valores capitalistas tendem a se articular e fundir no conjunto dos processos sociais e se traduzem, notadamente, por uma nova forma de utilizar o tempo, a qual põe em cheque a distinção entre tempo de trabalho e tempo de consumo. ${ }^{1} \mathrm{O}$ tempo humano se torna totalmente econômico, atenuando a fronteira entre produção social e produção econômica.

A destruição das distâncias une figuras de natureza diferente e transforma-as em séries de redes híbridas de participação global, abolindo tanto as divisões binárias do modelo de divisão científica do trabalho, quanto à sua ideologia homogeneizante e massificante. Toda a economia é permeada pelas redes de comunicação, cujas normas de funcionamento dissolvem as fronteiras espaçotemporais e contestam a figura linear e autoritária da divisão técnica do trabalho e seu caráter bipolar. Tendem a superar a lógica binária infraestrutura/superestrutura, produção/reprodução, trabalho/meios de produção e capital constante/capital variável. As atividades produtivas de forte conteúdo intelectual se tornam indistinguíveis e o tempo da invenção, enquanto criação contínua do "novo", se opõe ao tempo da repetição, ao tempo sem memória do capitalismo industrial.

A tecnologia intelectual reinventa incessantes relações singulares e diversas em redes multidimensionais, onde o trabalho aparece como o poder de agir de uma forma que é ao mesmo tempo singular e universal. Nessas novas formas comunitárias de criação de riquezas, o maior fator de produção, que é o trabalho coletivo intelectual, é assegurado pelas ações singulares do trabalho, as quais

\footnotetext{
${ }^{1} \mathrm{O}$ individuo, ao consumir informação, analisa, confronta e combina seus diversos conteúdos e, portanto, produz novas informações que podem ser, por sua vez, utilizadas no próprio processo de produção.
} 
criam continuamente novas construções coletivas e, simultaneamente, singularizam o que é comum. ${ }^{2}$

Todas as transformações observadas no conjunto das regularidades de acumulação (organização da produção, relação capital/trabalho, demanda social, formas institucionais etc.) geram, de modo confluente, um deslocamento da base social e produtiva do capitalismo. Elas esboçam os contornos de um novo padrão de acumulação, no qual o objeto de exploração não são atividades produtivas específicas, mas a capacidade universal de produzir, isto é, a atividade social abstrata. A ênfase passa da aquisição do conhecimento e sua objetivação no elemento material para a sua produção e construção como verdadeira força produtiva, motivo de exploração e fonte de valorização, vinculada numa rede difusa de dispositivos que regulam diretamente as práticas laborais.

\section{ECONOMIA DO CONHECIMENTO - SUA GÊNESE}

A Economia do Conhecimento foi estimulada, em grande parte, pelos conflitos de trabalho que se aceraram a partir da década de 1970, acentuando a queda das taxas de lucro e determinando a crise do regime fordista de acumulação. $\mathrm{O}$ aumento da qualidade intelectual do trabalho, que se deveu ao maior nível médio de formação e educação, incentivou o trabalhador a contestar a organização científica. Simultaneamente, aprofundaram-se as contradições entre as frações do capital, resultando na transferência da governança empresarial aos acionistas (Aglietta, 2001; Duménil e Levy, 2000). A redistribuição do lucro a favor dos dividendos, num contexto de desregulamentação financeira e de endividamento público excessivo, incentivou a financeirização da economia à escala mundial (Chesnais, 1997; Serfati, 1996).

$\mathrm{Na}$ sua ofensiva contra o surto da intelectuabilidade difusa do trabalho e contra a contração da sua parte no produto, o capital produtivo e comercial abre várias frentes de batalha: empreende um vasto projeto de reestruturação produtiva, visando o aumento da produtividade e a redução do custo da mão de obra; desloca boa parte das indústrias de bens assalariados para os países emergentes, por onde amplia seus territórios de exploração; empenha-se, ainda, a captar mais-valia informal, através da difusão das relações capitalistas para a totalidade da sociedade e da apropriação de novas externalidades, como os saberes tradicionais e as informações em rede.

Trata-se, nesse último projeto, de uma tarefa que extrapola o domínio da empresa e que exige a privatização de conteúdos sociais de produção realizados em redes humanas de criação e cooperação. Essas redes se ampliam graças às Novas Tecnologias de Informação e Comunicação (NTICs), que têm a particularidade de

\footnotetext{
${ }^{2}$ Sobre a relação singular/comum, ver Giorgio Agamben (1993), The Coming Community. University of Minnesota Press.
} 
serem, simultaneamente, objeto de consumo e ferramenta de trabalho. A função e uso das NTICs são construídos e inventados pelo próprio trabalhador-usuário; não podem funcionar independentemente dos conteúdos culturais, artísticos, ideológicos e técnicos. Não se dissociam, portanto, do conjunto complexo dos saberes que eles veiculam.

As NTICs se constituem em poderosos suportes de uma informacionalização que se amplia graças à multiplicação da cooperação e à crescente interconexão das redes virtuais. A performance dessa ferramenta técnica depende da inteligência, da criatividade e da capacidade de invenção do trabalho vivo que se apresenta como ação imediatamente cooperativa. A cooperação se realiza dentro de redes difusas e de dispositivos que produzem e regulam símbolos, linguagem, costumes, hábitos e práticas produtivas.

A interatividade dos significados produz sistemas simbólicos e tecnologias intelectuais, que colocam em movimento as formas comunitário-cooperativas como fonte de criação de valor. Consequentemente, a valorização se realiza no interior mesmo do processo de produção e difusão da informação, a qual não pode possuir valor se não é intercambiada, difundida e, portanto, socializada. Assim, a ação instrumental da produção econômica é unida à ação comunicativa das relações humanas, e isso dentro de redes diferenciais e múltiplas, e com suportes tecnológicos que apropriam ações a fins específicos. Nesse sentido, o conceito de tecnologia intelectual é assumido pelo conceito geral da dinâmica social. Precisamente, a escolha dos instrumentos técnicos resulta do confronto de poderes concorrentes na busca de melhores formas de valorização, e é essa busca que torna a informação fonte primordial de acumulação.

Nas novas relações sociais que se inscrevem no paradigma da produção do conhecimento por conhecimento, o capital busca constituir arranjos institucionais próprios e formar sistemas de organização em rede que permitem captar a força de trabalho coletiva e viva que deriva da exploração sistemática da informação e do compartilhamento do conhecimento. Nesse sentido, os direitos sobre a propriedade intelectual e acesso às redes constituem uma modalidade de captação de externalidades, uma forma poderosa para as hierarquias de valor e de exclusão. Esses direitos de acesso à rede e ao conhecimento em geral formam modernos cercamen$\operatorname{tos}^{3}$ que separam e privatizam um espaço virtualmente universal de produção e circulação da informação. Por meio deles, o capital realiza uma nova modalidade de explorar o trabalho vivo. A nova modalidade de exploração capitalista se concentra precisamente nessa externalidade, fruto do trabalho coletivo e da subjetividade que se cria de forma coletiva à medida que se comunica.

O contexto social produz, portanto, um bem coletivo que o capital busca

\footnotetext{
${ }^{3}$ Os primeiros cercamentos são cercamentos de terras comunais, ocorridos na Inglaterra ao longo dos séculos XVI e XVII, a fim de criar ovelhas para a produção de lã, cuja demanda estava em expansão devido às primeiras transformações industriais. Os cercamentos contribuíram na dissociação do trabalho dos meios de produção, na realização de excedentes de mão de obra no campo e na formação do proletariado.
} 
apropriar através de novas práticas de submissão formal, captando na esfera da circulação mais-valia independente e cooperativa. Nesta esfera, o capital organiza novas bases de exploração que tendem a dominar na relação capital trabalho, lembrando a fase capitalista do putting-out-system. ${ }^{4}$

\section{COPRODUÇÃO COMUNICATIVA}

A busca do excedente na esfera da circulação não obedece apenas à estratégia da empresa de escapar dos conflitos de trabalho, mas traduz o fenômeno da ampliação do espaço econômico. O capital trata de captar externalidades na totalidade deste espaço e garantir um grau superior de produtividade: desterretorializa-se para explorar as possibilidades infinitas de modulação mercadológica; privatiza o que é comum e reduz o espaço público, como, também, se descentraliza para captar os fluxos positivos da comunicação.

$\mathrm{Na}$ visão da Teoria Crítica da Comunicação, a codificação informática facilita a transmissão maciça da informação e permite socializar o que é individual e tornar cada singularidade, com a sua carga de experiência cultural, um elemento potencialmente constitutivo do processo privado de produção e circulação. Dentro dessa perspectiva, o modelo definido pelo computador de inteligência e comunicação envolve essencialmente atividades simbólicas de rotina, que são passíveis de codificação.

Enfatizando essas atividades, desenvolveu-se o conceito da indústria cultural dentro do modelo de estandardização e estereotipagem. Nessa teoria que se consolidou pela crítica da sociedade através da revelação da Superestrutura Ideológica (Marcuse, Adorno, Horkheimer Debord, Jameson, entre outros), as redes de participação são manipuladas do alto por uma superestrutura que, de forma unilateral, regula a opinião publica e a produz, impondo uma sociedade massificada que tende a agir e a pensar de maneira uniforme. O indivíduo é considerado um ser passivo e submisso, sem vontade própria; o seu pensamento é completamente inibido quando agrupado em alguma massa. As pessoas adeririam acriticamente aos valores impostos, se alienariam às imagens dominantes da sociedade do espetáculo (como em Debord) e os seus desejos se esbarrariam na comunicação uniformizada e dominada pela conexão consumista (como em Jameson). A linguagem do discurso midiático é vista numa ótica estreitamente unidimensional, onde a instrumentalização das coisas torna-se instrumentalização dos indivíduos, desconsiderando a intervenção dos homens na vida social e omitindo a complexidade da dimensão simbólica presente em todo ato comunicativo.

No entanto, esse espetáculo, que é ao mesmo tempo difuso e integrado, so-

\footnotetext{
${ }^{4}$ Nos primórdios do capitalismo, antes da vigência do processo manufatureiro no século XVII, o capitalista entregava ao produtor artesão a matéria-prima que este trabalhava em sua própria casa, geralmente com sua própria ferramenta, e transformava em produto acabado do qual o intermédio se apoderava.
} 
mente funcionaria se todas as frações do poder e todos os interesses delas convergissem para um único comando, que seria consciente e explicitamente dirigido no sentido de conspirar e ditar o espetáculo. Simultaneamente, o funcionamento deste pressupõe exógeno o mecanismo de comando: a disciplina social é uma voz externa que dita as práticas da sociedade, sem que haja interação entre o emissor e o receptor. $\mathrm{O}$ indivíduo estaria inserido num sistema social impessoal, anônimo e manipulável pela mídia. ${ }^{5}$

Perceber a sociedade de controle de forma unidimensional equivale a pensar as instituições como instâncias separadas e isoladas das forças sociais. Ora, as instituições (família, Estado, escola, mídia etc.) que são, por excelência, as protagonistas da inserção social, lideram o processo de construção das identidades e regulam a sociedade. A crise social se reflete plenamente nelas, impondo sua flexibilização. A crise das instituições se traduz por um movimento de mão dupla: o vazamento de seus valores específicos que se espalham para outros domínios, de um lado, e, do outro, a sua invasão e penetração por novos valores exógenos que as reconfiguram. A evolução da identidade social envolve, então, a produção de subjetividades, a qual não permanece fixa, mas constantemente modulada por inúmeras instituições híbridas e diferentes combinações fora das instituições. A crise das instituições significa, justamente, que as fronteiras entre elas estão sendo derrubadas, de modo que a lógica que funcionava principalmente dentro das paredes institucionais se espalha para todo o terreno social (Hardt e Negri, 2001, seção 2.6).

Para os pensadores que consideram a intersubjetividade (a escola de Palo Alto, Merleau-Ponty, Wittgenstein, Bourdieu, Morin e outros), a comunicação é vista dentro de um modelo circular e retroativo, no qual o receptor tem papel tão importante quanto o emissor. A ideia da circularidade expõe o caráter rotativo do sistema: o efeito volta à causa e a causalidade se move em espiral. Os indivíduos produzem a sociedade e ela própria retroage sobre os indivíduos, com sua cultura e sua linguagem. A essência da comunicação reside precisamente em processos relacionais e interacionais, onde o indivíduo é sujeito e agente, interpreta e simboliza ao mesmo tempo. Ou seja, as relações humanas passam a formar um vasto sistema de comunicação, onde o homem é produto e, também, produtor ${ }^{6}$. Todo comportamento humano passa a ter valor comunicativo e, como a comunicação não ocorre sobre fatos situados fora das relações sociais, ela cria realidades (Berger e Luckmann, 1992).

A Teoria Crítica não dá conta das mudanças nas relações capital-trabalho no contexto do paradigma da comunicação construtiva, porque concebe a coprodu-

\footnotetext{
${ }^{5}$ Sobre o poder da mídia, ver Edward Hermann e Noam Chomsky, Manufaturing Consent: The Political Economy of Mass media, Pantheon, Nova York. 1988.

${ }^{6}$ Pierre Lévy sustenta que a mensagem é um agente efetivo para a mente de quem a interpreta. Se um texto, uma mensagem ou alguma obra funcionam como mente é porque já foram assimilados, lidos, interpretados e importados como matéria mental e efetiva (Lévy, 1995). As qualidades afetivas da mensagem interiorizada são transferidas à própria mensagem.
} 
ção em rede não verdadeiramente como coprodução de informação e conhecimento, ${ }^{7}$ mas como mera troca de informações submetida à mesma lei de repetição que caracteriza a "produção de mercadorias por mercadorias". A interação é vista apenas em função de uma relação vertical entre os produtores e os usuários de bens e tecnologias, mantendo uma visão demasiadamente técnica e economicista dos novos fenômenos que se pretende explicar. Essa interpretação não rompe com o superado universo Smith-Taylor, em que a cooperação é passiva e estática, assegurada pelo encadeamento programado e sequencial de tarefas elementares (Veltz, 1999).

Essa visão, na teoria econômica, corresponde às correntes que consideram apenas a dimensão quantitativa do consumo da informação, vista através do conceito dos rendimentos crescentes, o qual abrange fenômenos como economias de escala e learning by doing, que são examinados sob o ponto de vista de externalidades em rede (Arthur, 1989). Essas correntes assumem o trabalho criativo (a invenção) como fator exógeno, limitando a análise do processo de invenção à análise do processo de difusão no campo da economia de uma produção que lhe é externa.

\section{O TRABALHO COOPERATIVO E COMUNICATIVO COMO FATOR ENDÓGENO — UM TRABALHADOR AGENTE E SUJEITO}

A abordagem evolucionista concebe a invenção, ao contrário da visão clássica e da abordagem utilitarista, como um processo endógeno, não linear, que se confunde com o processo de produção e que se retroalimenta envolvendo inúmeros agentes. O processo informativo é, portanto, um processo de criação, porque nele se define o objeto técnico inovador. Esse processo tem um ponto de partida que é o paradigma tecnológico (o estado das artes): um conjunto atual de tecnologias, princípios científicos e de questionamentos sobre problemas a resolver.

A teoria evolucionista constitui uma renovação fundamental da economia da inovação. Todavia, com sua visão essencialmente cognitivista das mutações, embora consiga explicar a evolução tecnológica dentro de um dado paradigma, não dá conta das mudanças qualitativas que levam a novos paradigmas. Presa ao mundo da escassez e dos rendimentos decrescentes que caracterizam a produção de mercadorias por mercadorias, essa teoria afirma a perpetuidade dos motivos tecnológicos e mercadológicos que se juntam para contrair os rendimentos de forma cada vez mais acentuada, à medida que se avança numa dada trajetória de inovação (Amendola \& Gaffard, 1998). Ela trata da especificidade do conhecimento e dos

\footnotetext{
${ }^{7}$ A informação é objeto de produção dos sistemas de valor, isto é, do conhecimento. Supunha-se, por convenção, que o conhecimento é a informação processada ou sistematizada pelo pensamento. Essa distinção só pode ser relativa, dado que a mente processa tudo que capta. A mente, aqui, é a capacidade humana de aprender e usar símbolos.
} 
recursos envolvidos na sua produção, mas ignora a especificidade do sujeito criativo, razão pela qual não pode tratar da dinâmica de inovação num sistema de produção de conhecimentos por conhecimentos.

Nessa nova dinâmica, em oposição, o uso da ferramenta técnica depende da performance do trabalho vivo concreto, heterogêneo e partilhado, onde criatividade e capacidade de invenção se apresentam como ação imediatamente intersubjetiva. Nela, as interações entre os produtores e os usuários representam relações de coprodução (Lundvall, 1999). O trabalhador, agente e sujeito, não se apresenta como força de trabalho heteroproduzida, mas como força de trabalho que se autoproduz e continua a se autoproduzir no tempo de trabalho e no tempo de não trabalho. O tempo separado do espaço do trabalho se torna um laboratório pós-industrial de criação e inovação.

Onde o processo de produção se caracteriza por elementos imateriais ligados às capacidades cerebrais e cognitivas, a cooperação não pode ser, como na abordagem da indústria cultural, reduzida e confundida com a cooperação tecnológica e comercial. Esta tem como finalidade central a redução da incerteza e a gestão da escassez, dentro do modelo industrial transformista de energia, onde a máquina impõe sua lei de funcionamento ao trabalho como abstrato e genérico. Na lógica da produção do conhecimento pelo conhecimento, o trabalho vivo não se incorpora na máquina e a reprodução do seu caráter se faz de forma concomitante ao ciclo produtivo em geral; as funções do trabalho coletivo vivo não são mais absorvidas na organização cientifica do trabalho.

Se a máquina incorporasse os aspectos coletivos do trabalho vivo, a produtividade aparente do trabalho diminuiria a favor do indicador de produtividade aparente do capital. O capital estaria acumulando trabalho morto e abandonando a sua função de extrair mais-valia a cada nova configuração do ciclo capital-mercadoria.

Nas teorias do crescimento econômico, os maiores avanços das últimas décadas se devem aos modelos que buscam integrar as condições do trabalho vivo complexo na unidade do ato produtivo e na continuidade do processo de valorização. Nestes modelos, conhecidos como modelos de crescimento endógeno, os ciclos não são mais determinados por variáveis nominais, como moeda e inflação, mas explicados, ora por mudanças tecnológicas (Prescott, 1986), ora pelo comportamento do mercado de trabalho (Summers, 1986; Mankiw, 1989). O trabalho complexo intelectual se torna tão importante nos novos processos inovativos que leva a teoria econômica a distingui-lo do trabalho homogêneo e considerá-lo como capital humano. $\mathrm{O}$ trabalho complexo ou qualificado se apresenta como resultado de um capital investido na formação do trabalhador, o qual o disponibiliza mediante uma renda.

Codificar o capital humano a fim de padronizá-lo e generalizar o seu uso sem o assentimento do trabalhador não é tarefa trivial para o capital. A apropriação de conhecimentos, competências intelectuais podem ocorrer independentemente de 
quem as possui, conferindo ao trabalhador maior poder de negociação. O trabalhador é particularmente qualificado quando adquire as condições de intervir na concepção e racionalização do processo de produção, na inovação de produtos, no nível da circulação da informação e na qualidade do próprio trabalho. Sendo assim, ele entra na formalização econômica do fator tecnológico e deixa de ser considerado como algo residual.

$\mathrm{Na}$ atividade cognitiva de criação, de transformação da informação e da incorporação desta no conhecimento do trabalho vivo, a extração da mais-valia pressupõe a reprodução e a preservação do trabalho complexo como trabalho vivo e não como bem de capital. A apropriação capitalista fica determinada pelas condições de subjugar o trabalho vivo na totalidade do processo de realização, enquanto trabalho vivo que se reproduz ao longo do processo como trabalho vivo independente do trabalho morto. "O marco do capitalismo cognitivo está no fato de que o conhecimento não se incorpora nem no trabalbo, nem na máquina, nem na organização" (Rullani, 2000).

No modelo entrópico de transformação industrial, onde prevalece a lei dos rendimentos decrescentes, as modalidades de divisão e organização do trabalho residem na especialização da máquina — na heterogeneidade das máquinas - que se opõe a um trabalho homogêneo, o qual se exterioriza como simples gasto energético, esforço muscular. Nesse mesmo modelo, a máquina é especializada, sua função e seu uso são determinados pela natureza dos conhecimentos que ela incorpora. Frente a essa máquina, o trabalho separado do conhecimento é desprovido de qualquer especificidade. A máquina, enquanto cristalização do saber e enquanto trabalho morto, impõe sua lei de funcionamento ao trabalho vivo.

Essa relação homem-máquina se inverte no paradigma da produção do conhecimento por conhecimento. Neste universo, enquanto o trabalho se confunde com a criação de usos, a máquina se desespecializa e homogeneíza. Essa novidade constitui uma verdadeira ruptura na história das técnicas, ao colocar em questão a relação que até então fixava um objeto técnico na sua função e designava ofícios e competências em função das ferramentas utilizadas.

Ao dissociar a máquina (hardware) do seu programa (software) e interconectar os agentes cooperativos, as NTICs conferem uma elevada maleabilidade aos instrumentos, cujo uso implica em variações constantes dos programas de funcionamento. Em outras palavras, o computador conectado à rede não possui uma função predeterminada, enquanto meta-máquina. Ele é uma caixa vazia que somente a forma como é preenchida lhe confere uma função ou uma utilidade. O que está implicado na produção, como produção criativa, não é mais a associação da capacidade homogênea da máquina com o trabalho abstrato e genérico, mas, sim, a capacidade heterogênea e subjetiva do trabalho em adquirir, acumular e valorizar conhecimentos, isto é, ressignificar os codificados saberes.

Esse trabalho intelectual nasce na esfera comum, se desenvolve na totalidade do campo social e se reproduz de forma endógena no tempo social de valorização, 
consumindo bens públicos, de ordem universal. Não é a divisão cientifica do trabalho que produz trabalho vivo, mas a cooperação social em torno de conteúdos culturais, artísticos, ideológicos e técnicos. A cooperação social corresponde a uma mobilização do indivíduo e dos coletivos do trabalho em redes de comunicação e valorização que, no contexto atual, se tornam objeto de consumo e ferramenta de trabalho ao mesmo tempo e, por isso, portadoras de uma mudança qualitativa maior, na qual emerge o fenômeno do uso como fator de produção.

O valor está no uso coletivo e este não está mais determinado pela máquina. É precisamente esse fenômeno que motiva as dúvidas acerca da rentabilidade das NTICs. Através dele pode-se entender o paradoxo da produtividade de Solow (Solow, 1978), em que a adoção de novas tecnologias exige inovação da parte de quem as adota. Consequentemente, a performance da ferramenta técnica depende da inteligência, da criatividade e da capacidade de invenção do trabalho vivo partilhado. Desde então, como constata Corsani, "não se pode associar [...] a imaterialidade do conhecimento à materialidade das mercadorias; não é mais possivel definir a produtividade do trabalho na sua relação interna ao capital" (Corsani, 2002, p. 183).

\section{A CRESCENTE IMPORTÂNCIA DA COMUNICAÇÃO E DO TRABALHO COOPERATIVO NOS PROCESSOS PRODUTIVOS E SUAS IMPLICAÇÕES NA ORGANIZAÇÃO DO TRABALHO}

O capitalismo industrial, ao desenvolver novos materiais e novos processos de produção, levanta a necessidade de criar novos valores de uso para os novos produtos. As oportunidades de acumulação não são, portanto, criadas apenas via ampliação quantitativa da demanda, mas incluem uma dimensão qualitativa, onde a comunicação não é limitada a uma mera transmissão de dados, mas abrange a articulação entre consumo e produção numa permuta contínua, que é, ela própria, objeto de produção e valorização. Na estrita cooperação entre mercado e produção, é essa permuta que permite detectar e criar desejos e anseios, os quais são transformados em necessidades (via publicidade) e, em seguida, respondidos por novos produtos.

No contexto da economia do conhecimento, dominada pelo imprevisível e pela incerteza, a cooperação é dinâmica, baseada em formas horizontais de comunicação, as quais demandam um trabalho polivalente e uma capacidade de ação e interação não prescritível. Quando se produz conhecimento por conhecimento, a cooperação se torna consubstancial à atividade criativa e se amplia graças à multiplicação e interconexão das redes virtuais que a tecnologia autoriza. Essa cooperação ampliada e geradora de valor não pode ser reduzida e confundida com aquela cooperação tecnológica e comercial que tem como finalidade central contradizer o fenômeno dos rendimentos decrescentes. 
A troca de informações não comporta nem perda nem sacrifício; escapa da lei do rendimento decrescente e, a fortiori, da lei da escassez. Seu consumo não é destruidor e não implica a depreciação ou o esgotamento da sua utilidade. Pelo contrário, o uso da informação é uma atividade criativa, pois, enquanto "conhecimento em ato", evolui com o seu uso subjetivo. O seu custo de reprodução é muito baixo e o seu valor agregado elevado e, em razão da cumulatividade, o seu custo marginal é decrescente. No entanto, ele é muito variável de um contexto para outro e é fortemente incerto, pesando sobre o processo de inovação.

A revolução informacional reconfigura os processos de produção, altera suas formas institucionais de regulação e abre espaço considerável para a acumulação. A produção de serviços e o manuseio de informações estão no coração da economia, apoiados na revolução da comunicação e da informática que transforma as práticas laborais, inserindo-as no modelo das tecnologias de informação e comunicação. Toda atividade econômica é permeada pela informação que age em todo o campo social. As técnicas tradicionais de máquinas industriais estão realmente sendo substituídas pela inteligência cibernética de informação e pelas técnicas de comunicação.

Contra a tese da indústria cultural está o próprio trabalho de rotina, que não requer apenas um trabalho de execução, como se pensa, mas implica o cumprimento de tarefas analíticas e simbólicas via manipulação inteligente e criativa. Quando um sistema (vivo) age no seu ambiente, ele interage com inúmeras fontes de informação, isto é, de incertezas. Ele precisa eliminar essas incertezas, causando negontropia ${ }^{8}$ adicional, porque o sistema informacional é uma atividade viva que possui a capacidade de reter e recuperar energia. Quanto maior seja o tratamento da incerteza, maior será a experiência adquirida. Como observa Atlan (1992, p. 145), o tempo de tratamento das incertezas se afirma criativo e agrega realmente valor ao trabalho informacional.

Além destas tarefas analíticas e simbólicas, ainda existe a outra face do trabalho coletivo vivo, constituída pelo trabalho afetivo de contato e interação humana, pelos serviços em geral, cujos produtos (satisfação, conforto, bem-estar) são intangíveis e envolvem uma vasta gama de atividades, como assistência médica, educação, finanças, transportes, segurança, entretenimento e publicidade. Em cada uma dessas formas de trabalho, os empregos são altamente movediços e envolvem flexibilidade e aptidões. São caracterizados em geral pelo papel central desempenhado por fatores como conhecimento, informação, afeto e comunicação. "A realidade econômica e social é definida menos pelos objetos materiais feitos e consumidos do que pelos serviços e relações co-produzidos [...] Cada vez mais, produzir significa construir comunalidades de cooperação e comunicação” (Hardt \& Negri, 2001, p. 323).

A demanda social corrobora com a tese da hegemonia do trabalho coletivo

\footnotetext{
${ }^{8}$ Negontropia ou neguentropia é a força que se opõe ao princípio da termodinâmica. É a capacidade de recuperar no ambiente a energia gasta, reciclar e reutilizá-la permanentemente na continuidade do trabalho entrópico.
} 
vivo, na medida em que o que se consome são, cada vez mais, os serviços, as tecnologias informáticas e comunicacionais e os conteúdos informacionais, culturais e artísticos, todos intimamente associados à ferramenta técnica NTICs, cuja peculiaridade encontra-se, precisamente, na indissociabilidade dos conteúdos que ela transporta e transmite.

A infraestrutura de informação, estruturada numa arquitetura ilimitada, inclusiva e diferenciada, é embutida nos novos processos de produção que lhe são totalmente inerentes. As NTICs permitem, não somente a manipulação e combinação das informações, como também impõem de forma transversal normas de funcionamento, participando assim na diluição das fronteiras entre os tempos históricos do capitalismo (consumo/produção, trabalho/não trabalho etc.). O tempo humano se torna então totalmente econômico, não mais através de sequências separadas e de lógicas binárias, como no regime fordista, mas via um continum de atividades. Consome-se primeiro bens que permitam o acesso à informação e que representam um capital. $\mathrm{O}$ acesso à informação, em seguida, permite produzir novas informações. Então, sob forma de consumo, constrói-se capital e, sob a forma de tempo, produz-se informação. Complica-se a medição do valor pelo tempo de trabalho, que é o centro da economia política.

Se o tempo do consumo (de serviços, informática, cultura etc.) e do lazer se transforma em tempo de aquisição e produção de novos conhecimentos (produzidos individualmente ou coletivamente dentro das redes), os tempos intermitentes de produção do assalariado são, eles, tempos de consumo (de aproveitamento) pela empresa desses próprios conhecimentos produzidos dentro e fora dela. A nova modalidade de exploração capitalista se estende precisamente ao fruto do trabalho coletivo e da subjetividade que se cria nas redes humanas de comunicação e cooperação. ${ }^{9}$

O movimento que reúne espaço e tempo universais, por meio da ação das forças sociais, não envolve apenas o econômico ou a dimensão social, mas abarca também o que Michel Foucault chamou de bios social, isto é, a forma de poder que se interioriza nos corpos e cérebros dos sujeitos e os regula por dentro (Foucault, 1994). Essa inter-relação dos tempos e dos espaços da vida e do trabalho gera um deslocamento radical da base social e produtiva do capitalismo, forçando o capital a sair, como sinaliza Dieuaide: "de uma lógica de valorização fundada no controle direto do processo de produção, [para entrar] numa lógica de valorização tentacular, baseada no uso e no consumo do saber e localizada na totalidade da vida social" (Dieuaide, 2002, p. 76-89).

\footnotetext{
${ }^{9} \mathrm{Na}$ lógica do conhecimento por conhecimento, o exterior à produção tende a ser formado nas próprias relações de produção e reprodução. O que era exterior à produção e às relações de produção é dissolvido na universalidade da criação humana, tornando impossível qualquer fronteira entre produção social e produção econômica. As externalidades podem ser consideradas como internalidades à esfera da produção do conhecimento.
} 


\section{UMA LÓGICA DE INOVAÇÃO PERMANENTE}

A acumulação na base da comunicação é sinônimo de uma situação de inovação permanente, em que a valorização se sustenta no tempo subjetivo e intersubjetivo da criação, isto é, no trabalho vivo e coletivo. A economia política não prevê esse caso em que o conhecimento, enquanto expressão da capacidade inovadora das relações subjetivas, passe a predominar no processo de realização de valor. Trata-se de uma passagem de uma lógica de produção para uma lógica de inovação. Evidentemente, no modelo industrial existe inovação, mas ela é relativamente uma exceção, pois a valorização se baseia essencialmente na dominação do tempo de reprodução de mercadorias padronizadas, produzidas com tecnologia mecânica. O tempo em questão é um tempo sem memória, a não ser a memória do gesto repetido e da cooperação estática, inscrita na divisão técnica das tarefas e determinada segundo as normas da organização científica do trabalho. No capitalismo informacional, essa exceção que é a inovação se torna regra, pois a valorização nesse novo regime deriva da produção do conhecimento, no tempo da sua produção, difusão e socialização que as NTICs permitem enquanto tecnologias cognitivas e interconectadas. $\mathrm{O}$ conhecimento nasce e se difunde de forma heterogênica ao longo das trajetórias desenhadas por relações criativas cumulativas, cooperativas e amplamente socializadas dentro de contextos de produção e de uso. Pode-se, nesse contexto, evocar a ideia de regime de inovação.

O que entra em jogo na produção criativa é a energia da memória que cria e reproduz infinitamente símbolos que se referem ao pensamento e ao conhecimento. Essa capacidade da memória é anti-econômica, porque permite, simultaneamente, criar, dar, reter, gastar e conservar a custos limitadíssimos ou nulos. A memória contém nela a ferramenta, a matéria prima e a energia necessárias à produção e reprodução do conhecimento. A memória, principal meio de produção do conhecimento, possui a característica de se exteriorizar sem, para tanto, se alienar, escapando da relação sujeito-objeto própria às teorias do valor, as quais descrevem a produção como objetivação do sujeito no que produz.

Bérgson mostrou que toda encarnação da memória (sensório-motora, intelectual ou tecnológica) cumpre a função de afrouxar os mecanismos que servem a manter o trabalhador com a mente cativada e absorvida pela ação finalizada. Ele parte da "fabricação", a qual, embora opere conforme um plano e uma finalidade, cria condições que permitem à mente se "distrair" e não permanecer completamente absorvida pela realização de tarefas predeterminadas, dispensando-a de se submeter inteira e exclusivamente ao domínio material (Bérgson, 1989, p. 634). Nessas condições, pode-se assimilar na fábrica, não somente o trabalho, mas também a "força da invenção", a qual atinge, com o predomínio dos serviços, um estágio nunca antes visto.

Para que o capital consiga dominar essa força de invenção, com as mesmas práticas de dominação do trabalho material (o da ação finalizada), separando o trabalho dos meios de produção, deverá, simultaneamente, transformar o traba- 
lhador imaterial em um paradoxal autômato-criativo e reduzir a ação da memória a um simples trabalho reprodutivo. Em outros termos, o capital deverá conseguir a separação da faculdade de criar (ideias, imagens, sentimentos) da de se reproduzir (rememorizar).

\section{CONDIÇÕES DE EXPLORAÇÃO}

Na economia política, uma vez realizada a separação entre o trabalho e os meios de produção, o processo de trabalho se torna indistinguível do processo de valorização. É precisamente essa coincidência que define a submissão real do trabalho ao capital. No sistema de produção de conhecimento, onde a valorização ocorre no tempo subjetivo e intersubjetivo da criação, o capital pode encontrar dificuldade em assegurar essa submissão. Isso porque a natureza da atividade subjetiva e a natureza do objeto implicam na livre produção e socialização do conhecimento. A lógica especificamente capitalista da submissão real é abalada pelo fato de que não se pode comandar a invenção e pelo fato do conhecimento não permitir ser apropriado e parcelado segundo os princípios do individualismo possessivo.

A economia política desnuda o trabalho de toda criatividade, reduzindo-o a um simples gasto de trabalho-abstrato. No decorrer do processo de objetivação do trabalho simples, o trabalhador individual, desaparece no coletivo do trabalho combinado. No Capítulo Inédito, Marx afirma que pouco importa que esse trabalho seja manual ou intelectual. Todas as categorias de trabalho e qualificações aparecem como "funções das forças de trabalho incorporadas no conceito imediato de trabalho produtivo". É, portanto, absolutamente indiferente que a função de um trabalhador ou de outro, simples relação de trabalho coletivo, seja mais próxima ou mais distante do trabalho manual direto (Marx, 2004, p. 110).

No entanto, Marx evocou, sem integrar na sua teoria do valor, a relação entre a potência do trabalho vivo, indeterminação capaz de qualquer determinação, $\mathrm{e}$ sua atualização nos produtos. O processo histórico de desenvolvimento do capital representa um processo de transferência das capacidades vivas do trabalho simples para o trabalho morto; um processo de objetivação da informação social na máquina; um processo de reificação do conhecimento na codificação redundante do trabalho morto. Pode-se afirmar, desde então, que a máquina é uma redundância concreta: uma informação congelada em suas formas materiais e em suas possibilidades dadas de movimento. Suas capacidades para transformar a matéria dependem diretamente do conhecimento acumulativo extraído das forças produtivas e coletivas. Consequentemente, o trabalho intelectual que, com o tempo se tornou dominante, se revela como força produtiva absoluta.

Marx já havia apontado para a importância na valorização do capital das capacidades intelectuais criativas e da formação geral contida no convívio social. São as qualificações culturais e educacionais gerais do trabalhador que geram o seu 
valor de uso e de troca. Foi nessa perspectiva que o autor previu, com genialidade, a perda da capacidade da força do trabalho simples em gerar mais-valia, a partir do momento em que o manejo das ferramentas é incorporado pela máquina, [eliminando dessa forma] tanto o seu valor de uso, quanto o seu valor de troca $(\mathrm{O}$ Capital, I). No seu tempo, em que a atividade laboral tratava de um trabalho direto de transformação material, ele não pôde ir adiante. Todavia, ele mostrou nos Grundrisse que essa ruptura entre trabalho imediato e trabalho mediato tende a subtrair do capital a sua fonte de valorização e extração da mais-valia.

Embora a relação entre trabalho intelectual e invenção estivesse ainda vaga e o trabalho vivo tivesse como único objetivo a transformação da matéria, Marx conseguiu vislumbrar os poderes do trabalho que são sugeridos pelos poderes do conhecimento, da comunicação e da linguagem. O intelecto geral de Marx é uma inteligência coletiva, criada por conhecimentos acumulados. $\mathrm{O}$ valor do trabalho no contexto pós-moderno é dessa forma realizado por uma nova força de trabalho universal e concreta, por meio da apropriação e livre utilização das renovadas forças produtivas.

Marx não chegou a incluir na sua teoria de exploração esses conceitos de potência e ato do conhecimento, que permaneceram praticamente no estádio da intuição e metáfora. A sua inclusão teria complicado a construção da teoria do valor-trabalho, num contexto em que o trabalho intelectual representava um mero auxílio à transformação da matéria e no qual o conjunto dos fenômenos que se referem a imagens, lembranças, linguagem e afeto, ainda não se constituiu como fonte explícita de valorização.

Quando o trabalho tende a se tornar predominantemente uma força social animada pelos poderes do conhecimento e da linguagem, o insumo não é necessariamente fornecido pelo capital, nem mesmo o meio de produção. A informação, como trabalho vivo complexo, é realizada na unidade do ato produtivo e do processo de valorização. Embora inserida como in put no ciclo da realização, ela não se deprecia ao longo do processo produtivo, a sua energia não se extingue no processo de transformação. Ela não é um estoque que se esgota com o uso, mas um fluxo que se mantém, alimenta e valoriza. ${ }^{10}$

Contrariamente ao tangível bem-mercadoria, a informação é um bem que só existe enquanto ideia e, por não ser um bem raro, ela não implica necessariamente intercâmbio desigual, alienação e espoliação. A sua valorização deriva da socialização que, por sua vez, se baseia na emanação, na agregação recíproca, isto é, na capacidade de, simultaneamente, dar e reter, reproduzindo-se concomitantemente ao ciclo de criação de valor. Esse fenômeno pode representar um marco na evolução do capitalismo, uma nova fronteira que, da mesma forma que supera o mode-

\footnotetext{
${ }^{10} \mathrm{O}$ conhecimento também não é um estoque. Considerá-lo como tal pode ser útil para distingui-lo da informação, mas isso engana na medida em que a acumulação do conhecimento pressupõe, por definição, a renovação das estruturas.
} 
lo entrópico industrial, de conversão mercantil da energia motriz, revela o limite da objetivação e da mercantilização do trabalho vivo. Esse limite é o ponto de partida para o "proletariado social" reconhecer o seu próprio valor de uso, sua autonomia e sua esperança de libertação. A sociedade pode perceber o novo uso de máquinas, onde o proletariado não é explorado, onde ele não é mais apenas uma parte da produção, mas um agente autônomo de produção que se reapropria de novos espaços e novas liberdades. Essa possibilidade vai totalmente de encontro às teses que prevêem a marginalização do trabalho.

Na produção do conhecimento pelo conhecimento, complica-se a absorção do trabalho vivo na organização científica e na materialidade do produto; afrouxa-se a dependência do trabalho vivo em relação ao trabalho morto, dificultando a separação entre os meios de produção e as forças produtivas. Consequentemente, a produção do conhecimento não garante a coincidência entre o processo de trabalho e o processo de valorização. Nela, a produção e a valorização (invenção e inovação) são agenciadas em função do seu conteúdo criativo.

Libertado da sua condição de incorporado, o conhecimento pode ser reproduzido, trocado e utilizado de forma separada do capital. Mesmo que o dinheiro compre o trabalho para produzir conhecimento, a compra não assegura o comando, pois o trabalho cognitivo não precisa ser necessariamente combinado ao capital para ser produtivo. Mesmo que o trabalho intelectual dependa das encomendas do capital, ele não é mais uma função capitalista. Ele é socializado "em si e para si”, pois a cooperação se torna totalmente inerente ao trabalho, o qual corresponde a uma participação no crescimento do conhecimento junto com outros componentes do trabalho vivo. Essa associação produz redes e novas tecnologias nas quais a própria circulação da informação é fonte de valorização.

Dentro das redes de conhecimento, cada subjetividade se torna, ao mesmo tempo, sujeito de participação e agente independente de produção e consumo. Esses espaços confundidos de valorização não são apenas substitutos do espaço da fábrica como modalidade de organização e gestão das relações de produção, mas espaços de circulação interna ao próprio trabalho cooperativo, onde os indivíduos vivem e funcionam socialmente em condições essenciais para a acumulação. Nesta, a autovalorização do trabalho excede a si mesma e se move por "sobressaltos intermitentes" da capacidade de invenção do capital humano, como Schumpeter já o percebia.

A cooperação criativa passa, graças à constituição das redes informacionais, a preexistir ao capital. Ou seja, o capital, para valorizar-se, não precisa fazer prova de hegemonia pela iniciativa de predispor de estruturas de organização do trabalho. As NTICs propiciam-lhe a possibilidade, enquanto ainda condição do processo produtivo, de encarregar o trabalhador de assumir na vida privada uma parte crescente do engajamento profissional e de se munir de um conjunto de ferramentas de produção, que até então eram fornecidas pela empresa. Ele se "desapega" da base material das relações de exploração e entrega a gestão dessa base aos co- 
letivos de trabalho, mantendo, no entanto, a capacidade estratégica de intermediação, ativação e controle dos fluxos de produção e de troca no âmbito das próprias relações de trabalho. A sua ação se volta para a gestão e exploração das capacidades intelectuais criativas, que perpassam o domínio da fábrica e se encontram potencialmente contidas nas relações sociais de cooperação.

Nesse terreno social de criação, as relações de produção se confundem com as forças produtivas e inviabilizam a apropriação da força criativa do trabalho vivo coletivo via submissão real. Resta ao capital a prática da submissão formal, associada à imposição de uma nova política de apropriação, mediante os "direitos de propriedade intelectual”, de um lado, e, do outro, via distribuição do tempo em tempo curto de trabalho remunerado e em tempo maior não remunerado ou subremunerado de trabalho reservado à aquisição de informações. A solução é ideal, pois permite elevar, de vez, tanto a mais-valia absoluta quanto a relativa.

Uma informação pode participar na valorização do capital quando acelera no universo mercantil a revelação de um conhecimento coletivo a ser explorado; quando restringe a fuga ou o êxodo do trabalho vivo imaterial do regime de reprodução mercantil ${ }^{11}$ e quando reforça a produção do trabalho vivo pelo trabalho vivo de forma dependente do trabalho morto. Mas ela pode aumentar, também, o poder do trabalho, quando permite o uso coletivo e gratuito do conhecimento, quando autoriza a abertura de novos espaços de trabalho menos subjugado e quando obriga o empregador a reconhecer a produtividade direta do trabalho vivo como trabalho vivo, não como trabalho submetido ao capital.

\section{CONSIDERAÇÕES FINAIS}

Esse paradoxo da informação revela o caráter conflitante da nova articulação capital-trabalho. Representa um desequilíbrio fundamental que o novo capitalismo terá que enfrentar. O êxito do capital nesse intento dependerá da sua capacidade em sustentar a sujeição do trabalho criativo, cuja valorização se torna cada vez mais autônoma em relação às estruturas materiais de comando; dependerá da sua capacidade em comandar uma produção cuja especificidade se encontra na impossibilidade de ser pensada e organizada nos mesmos modos da ação finalizada (planejada e executada na empresa). Essa empreitada pressupõe a redefinição das modalidades de exploração e comando, pois o fruto do trabalho criativo é bastante incerto e imprevisível e não pode ser controlado da mesma forma que o trabalho abstrato, alocado, simples e repetitivo. O lugar de efetivação do trabalho coletivo é indeterminável, o que leva o capital a estender a sua lógica de valorização tentacular a novas esferas (públicas, "íntimas" e afetivas), apontando para a dissemina-

\footnotetext{
${ }^{11}$ Seria adequado caracterizar essa fuga como um moderno quilombo.
} 
ção dos conflitos sociais pela totalidade da vida social e reafirmando a busca pelo excedente como elemento determinante da dinâmica do capital.

As performances inovadoras são diretamente associadas à importância do investimento coletivo em infraestrutura, instrução, formação e pesquisa, cujo custo é amplamente socializado. É nesse sentido que os direitos sobre a propriedade intelectual e acesso às redes constituem uma forma poderosa para as hierarquias de valor e de exclusão; novos encravamentos que separam e privatizam um espaço virtualmente global de produção e circulação do conhecimento. No entanto, as novas tecnologias de rede também oferecem à força coletiva do trabalho a possibilidade de construir, independentemente do capital, sua própria estrutura de coordenação e integração, de modo a contestar a dominação do capital e complicar a subordinação real. É nessa articulação que reside o novo foco de conflitos entre o capital e o trabalho.

\section{REFERÊNCIAS BIBLIOGRÁFICAS}

AGLIETTA, M. (2001) Macroeconomia Financeira, Ed. Loyola.

AMENDOLA, M. \& GAFFARD, J.L. (1998), Out of equilibrium. Clarendon Press Oxford.

ARTHUR, B. (1989), “Competing technologies, increasing returns and lock-in by historical events”, Economic Journal, vol.3. pp. 116-131.

ATLAN, H. (1992), Entre o cristal e a fumaça, Jorge Zahar, São Paulo.

BERGER \& LUCKMANN (1992), A construção social da realidade, Vozes, Petrópolis.

BERGSON, H. (1889), L'évolution criatrice. Ed. PUF, Paris, França

BOURDIEU, P.; PASSERON, J.C. (1982), A economia das trocas simbólicas. Perspectiva. São Paulo.

CHESNAIS, F. (1997), L'émergence d'un régime d'accumulation à dominante financière, La Pensée, $\mathrm{n}^{\circ} 309$.

CORSANI, A. (2002), “Element d'une rupture: l'hypothèse du capitalisme cognitif”, em: vers um capitalisme cognitif, orgs. Azais, Corsani, Dieuaide, L'Harmathan, Paris. pp 173-188.

DEBORD, G. (1994), Society of the spectacle, Zone Book, Nova York.

DIEUAIDE, P. (2002), "Nouvelles technologies, nouvelle dynamique du capitalismo", em: vers um capitalisme cognitif, orgs. Azais, Corsani, Dieuaide, L'Harmathan, Paris. pp 90-114.

DUMÉNIL, G., LÉVY, D. (2000), Capital financiero y neoliberalismo: un análysis de classe, pp. 67 à 91", em: Guerrero, D. (Org.). Macroeconomía y crisis mundial, Trotta, Madrid.

FOUCAULT, M. (1994), “Les mailles du pouvoir”, Dits e écrits. Gallimard, Paris. pp. 182-201.

HABERMAS, J. (1984), Theory of communicative action. Beacon Press. Boston.

HARDT, M.\& NEGRI, A. (2001), Império. Record, São Paulo.

JAMESON, F. (1991), "Postmodernism, or the cultural logic of late capitalism", em The condition of postmodernity, orgs. Durham e Harvey, University Press, Oxford.

LEVY, P. (1995), Qu'est ce que le virtuel? Ed. La Découverte, Paris, França.

LUNDVALL, B. A. (1999), "Spacial division of labour and interactive learning”, Revue d'Economie Régionale e Urbaine, No. 3, pp. 469-488.

MARX, K. (2004), Capítulo VI inédito de O Capital, ed. Siciliano (trad.). São Paulo.

MARX, K. (1985), Grundrisse: lineamientos fundamentales para la critica de la economia politica 1857. Tomo I, Tradução Fundo de la Cultura Económica, México.

MERLEAU-PONTY, M. (1965), Phénoménologie de la perception, Payot. Paris. 
PRESCOTT, E.C. (1986), “Theory ahead of business cycle measurement”, Quarterly Review, Federal Reserve Bank of Minneapolis, v.10, n.4. pp. 641-654.

QUÉRÉ, L. (1991), D’um modèle épistemologique de la communication à um modèle praxéologique. Réseaux, 46/47, Paris.

RULLANI, E. (2000), Le capitalisme cognitive: du déja vu? Multitudes no 2, pp. 87-97.

SERFATI, C. (1996) "Le rôle actif des groupes à dominante industrielle dans la financiarisation de l'économie”, em CHESNAIS, F. (Org), La Mondialisation Financière, Genèse, enjeux et cô̂ts. Ed. Syros.

SUMMERS, L.H, (1986), “Some skeptical observations on real business cycle theory”, Quarterly Review, Federal Reserve Bank of Minneapolis, vol.10, n.4, pp. 303-343.

VELTZ, P. (1999), “Territoires innovateurs: de quelle innovation parle-t-on?”, Revue d'Economie Régionale e Urbaine, No. 3, pp. 607-616. 